\title{
Quality and persistence of forages in the Northern Great Plains
}

\author{
MARSHALL R. HAFERKAMP, ELAINE E. GRINGS, R.K. HEITSCHMIDT, AND MICHAEL D. MACNEIL
}

Authors are Rangeland Scientist, Research Animal Scientist, Supervisory Rangeland Scientist, and Research Geneticist, USDA-ARS, Fort Keogh Livestock and Range Research Laboratory, Miles City, Mont. 59301.

\begin{abstract}
Integrating use of seedings of perennial cool-season grasses with native range is used to increase available forage and for maintaining a high plane of nutrition for grazing livestock. Our goal was to evaluate performance of yearling cattle and stand persistence of 3 released wheatgrass cultivars. Twice replicated 3-ha pastures were seeded to 'Rosana' western wheatgrass [Pascopyron smithii (Rydb.) A. Love], 'Luna' pubescent wheatgrass [Elytrigia intermedia (Host) Nevski], and 'Hycrest' crested wheatgrass \{[Agropyron cristatum (L.) Gaertn.] ssp. desertorum (Fisch. ex Link) A. Love\} in autumn 1994. Yearling steers $(n=8)$ grazed from 9 May to 12 June 1997 and 24 April to 15 June 1998. Yearling heifers grazed from 27 April to 18 June 1999. Hycrest produced the largest herbage standing crop in spring 1997 (912 $\left.\mathrm{kg} \mathrm{ha}^{-1}\right)$ and $1998\left(1,223 \mathrm{~kg} \mathrm{ha}^{-1}\right)(\mathrm{P}<0.05)$, but by spring 1999 standing crops averaged $656 \mathrm{~kg} \mathrm{ha}^{-1}$, and cultivars were not significantly different. Digestible organic matter standing crop did not differ among pastures of seeded species, but declined $(\mathrm{P}<$ 0.05) from May to June each year. Crude protein standing crop varied among cultivars $(P<0.05)$ in April and May 1998 and May 1999; however, no clear trends emerged. Crude protein standing crops consistently declined from April-May to June. Average daily gains were similar among cultivars in 1997, but greater $(\mathrm{P}<\mathbf{0 . 0 5})$ on Hycrest $\left(1.28 \mathrm{~kg} \mathrm{day}^{-1}\right)$ than Rosana $(1.03 \mathrm{~kg}$ day $\left.^{-1}\right)$ in 1998. Gains on Hycrest $\left(0.74 \mathrm{~kg} \mathrm{day}^{-1}\right)$ and Rosana $(0.78$ $\left.\mathrm{kg} \mathrm{day}^{-1}\right)$ were greater $(P<0.05)$ than on Luna $\left(0.52 \mathrm{~kg} \mathrm{day}^{-1}\right)$ in 1999. These findings show in some years, Hycrest provided more forage in spring than Rosana, and will allow an increase in livestock numbers. Based on the encroachment of invading species, persistence of Luna is marginal of the $335-\mathrm{mm}$ precipitation zone in the Northern Great Plains.
\end{abstract}

Key Words: Agropyron spp. Pascopyron smithii, Elytrigia intermedia, Hycrest, Luna, Rosana, crude protein, digestibility, standing crop

The authors express appreciation to the USDA-ARS Forage and Range research group, Logan, Utah, for providing seed for this study and personnel of USDAARS and Montana Agr. Exp. Sta. located at Fort Keogh Livestock and Range Research Laboratory for their diligent efforts in helping carry out this research.

This paper is a contribution from the USDA-ARS and Montana Agr. Exp. Sta., Miles City, Mont.

The USDA-ARS, Northern Plains Area, is an equal opportunity/affirmative action employer, and all agency services are available without discrimination.

${ }^{1}$ Mention of any trade name or proprietary product does not constitute a guarantee or warranty by the authors or USDA-ARS nor does it imply the approval of these products to the exclusion of others.

Manuscript accepted 3 Nov. 01

\section{Resumen}

La integración de siembras de zacates perennes de estación fría con el pastizal nativo es usado para incrementar la disponibilidad de forraje y para mantener un plano nutricional alto del ganado en apacentamiento. Nuestra meta fue evaluar el comportamiento de novillos y vaquillas y la persistencia de la poblaciones de 3 cultivares liberados de "Wheatgrass". En otoño de 1994, en potreros de 3 ha repetidos 2 veces, se sembraron "Western wheatgrass" [Pascopyron smithii (Rydb.) A. Love] variedad 'Rosana', "Pubescent wheatgrass" [Elytrigia intermedia (Host) Nevski] variedad 'Luna' y "Crested wheatgrass" \{[Agropyron cristatum (L.) Gaertn.] ssp. desertorum (Fisch. ex Link) A. Love $\}$ variedad 'Hycrest'. Los novillo $(n=8)$ apacentaron del 9 de mayo al 12 de junio de 1997 y del 24 de abril al 15 de junio de 1998. Las vaquillas apacentaron del 27 de abril al 18 de junio de 1999. La variedad 'Hycrest' produjo la mayor cantidad de biomasa en pie en $1997\left(912 \mathrm{~kg} \mathrm{ha}^{-1}\right)$ y en $1998(1,223 \mathrm{~kg}$ $\left.\mathrm{ha}^{-1}\right)(\mathrm{P}<0.05)$, pero para la primavera de 1999 la biomasa en pie promedió $656 \mathrm{~kg} \mathrm{ha}^{-1}$ y no hubo diferencia significativa entre cultivares. La MO digestible de la biomasa en pie no difirió entre las especies sembradas, pero disminuyó $(P<0.05)$ de mayo a junio de cada año. La proteína cruda del forraje en pie varió entre cultivares $(P<0.05)$ en abril y mayo de 1998 y en mayo de 1999; sin embargo, no se definieron tendencias claras. La proteína cruda disminuyó consistentemente de abril-mayo a junio. En 1997, las ganancias diarias promedio fueron similares entre cultivares, pero en 1998 fueron mayores $(P<0.05)$ para 'Hycrest' $\left(1.28 \mathrm{~kg} \mathrm{day}^{-1}\right)$ que para 'Rosana' $\left(1.03 \mathrm{~kg} \mathrm{day}^{-1}\right)$. En 1999, las ganancias en 'Hycrest' $\left(0.74 \mathrm{~kg} \mathrm{day}^{-1}\right) \mathrm{y}$ 'Rosana' $\left(0.78 \mathrm{~kg} \mathrm{day}^{-1}\right)$ fueron mayores $(P<0.05)$ que las obtenidas con 'Luna' $(0.52 \mathrm{~kg}$ day $\left.^{-1}\right)$. Estos hallazgos muestran que en algunos años 'Hycrest' provee más forraje en primavera que 'Rosana', lo que permitirá un aumento en el número de ganado. Basado en la dispersión de especies invasoras la persistencia de 'Luna'es marginal en la zona de precipitación de $335 \mathbf{~ m m}$ de las Grandes Planicies del Norte.

Pastures seeded to perennial cool-season grasses can be used to reduce grazing pressure on native ranges and provide quality forage for livestock at selected seasons (Wight et al. 1983). Many seeded grass species, cultivars, and hybrids have been evaluated for forage production and nutrient quality and persistence on selected sites, then subsequently recommended for use over a wide area (Vallentine 1980, Currie and White 1982, Currie et al. 1986b). Although some have been evaluated for livestock preference (Truscott and Currie 1989, Borman et al. 1991), few have 
been evaluated for livestock performance before release (Smoliak 1968, Smoliak and Slen 1974, Kilcher and Lawrence 1979, Hart et al. 1983, Hofmann et al. 1993). Also, studies by Moore et al. (1995) and Vogel et al. (1993) clearly show that grazing studies provide additional information on livestock rate of gain and stand persistence that cannot be obtained with small plot evaluations. For example, Papadopoulos et al. (1995) compared orchardgrass (Dactylis glomerata L.) cultivars in haying and grazing systems and found the cultivars ranked differently between the 2 systems. Thus, it appears that grazing trials are needed to compare experimental cultivars. The goal of this project was to evaluate livestock performance and stand persistence of introduced and native cultivars of 3 released wheatgrasses.

\section{Materials and Methods}

\section{Study Site}

Research was conducted at the Fort Keogh Livestock and Range Research Laboratory $\left(46^{\circ} 22^{\prime} \mathrm{N} 105^{\circ} 5^{\prime} \mathrm{W}\right)$ near Miles City, Mont. Elevation on the study site is $719 \mathrm{~m}$. Regional topography varies from rolling hills to broken badlands with small intersecting ephemeral streams flowing into rivers in broad, nearly level valleys. This area is representative of the semi-arid mixed grass prairie of the Northern Great Plains. Indigenous vegetation on the 22,500-ha research station is a gramaneedlegrass-wheatgrass (Bouteloua-StipaAgropyron) mix (Küchler 1964). Annual precipitation averages $343 \mathrm{~mm}$, with about $60 \%$ received from April through September (Fig. 1). Daily temperatures range from $>38^{\circ} \mathrm{C}$ during summer to <$40^{\circ} \mathrm{C}$ during winter. The average frost-free growing season is 150 days. Soils on the site are a composite of Glendive loam (coarse-loamy, mixed, superactive, calcareous, frigid Aridic Ustifluvents) and Havre loam (fine-loamy, mixed, superactive, calcareous, frigid Aridic Ustifluvents) with 0 to $2 \%$ slopes.

\section{Treatments and Experimental Design}

Six, 3-ha pastures, previously seeded to crested wheatgrass [Agropyron cristatum (L.)] or Russian wildrye [Psathyrostachys juncea (Fisch.) Nevski], combined with alfalfa (Medicago sativa L.) were used in this study. Seedbeds were prepared by spraying vegetation with Roundup [Glyphosate,N-(phosphonomethyl) glycine] in early summer 1994 , discing in late summer, and then rototilling and seeding with the Range Improvement Machine (RIM) (Currie et al. 1986a) during late autumn. Each forage species was planted in 2 of 6 pastures arranged in randomizedcomplete-block design with 2 blocks of 3 treatment species in autumn 1994. Forages were 'Rosana' western wheatgrass [Pascopyron smithii (Rydb.) A. Love], 'Luna' pubescent wheatgrass [Elytrigia

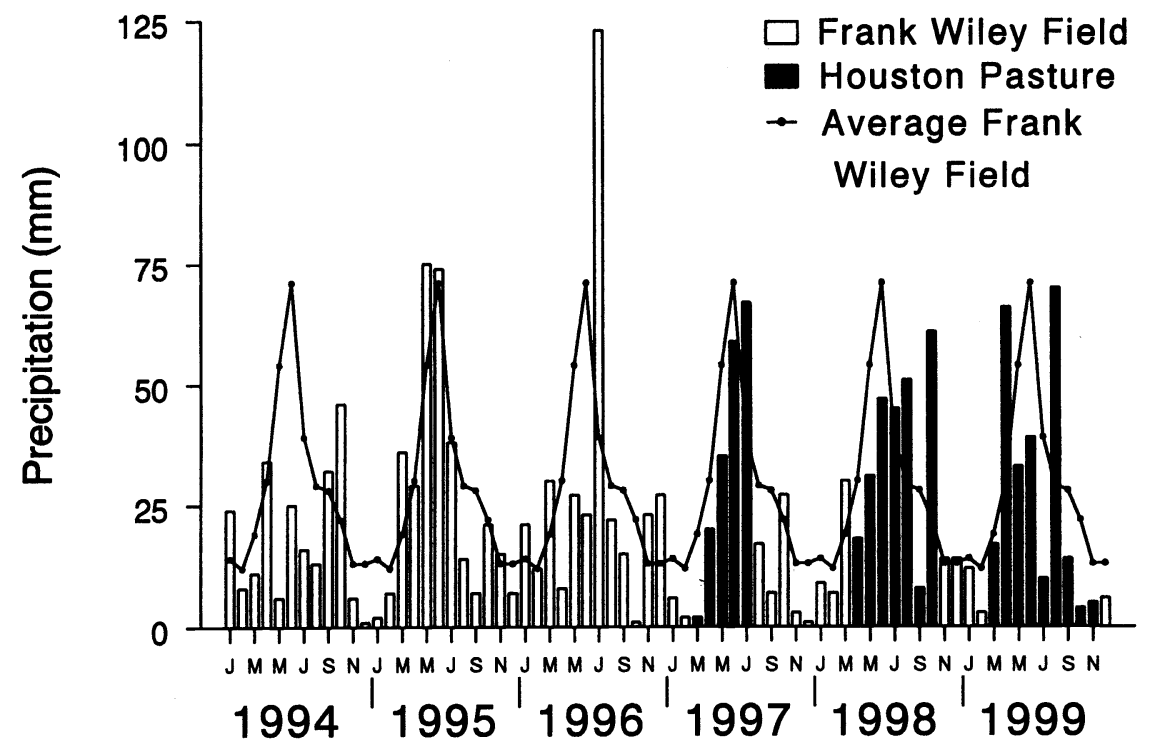

Fig. 1. Precipitation recorded on the Houston pasture study site (shaded bars) at Fort Keogh and at the Frank Wiley Airfield located about $4 \mathrm{~km}$ from the study site (open bars) and long-term average from Frank Wiley Airfield (National Oceanic and Atmospheric Administration 1994-1999). intermedia (Host) Nevski], and 'Hycrest' crested wheatgrass $\{[$ Agropyron cristatum (L.) Gaertn.] ssp. desertorum (Fisch. ex Link) A. Love . Seeds were drilled in rows on $30-\mathrm{cm}$ centers with the RIM machine (Currie et al. 1986a). Seedings were hayed but not grazed during 1995 and 1996. Stubble resulting from growth after grazing during 1997, 1998, and 1999 was left standing.

Each 3-ha pasture was stocked with 8 crossbred yearling steers of British breed origin (Bos taurus) from 9 May to 12 June 1997 and 24 April to 15 June 1998. Due to lack of availability of steers, each pasture was stocked with purebred yearling Hereford heifers from 27 April to 18 June 1999. Livestock were handled according to protocol approved by the Fort Keogh Livestock and Range Research Animal Care Committee. Availability of herbage in the least productive pasture (block 1 Luna) determined the time of livestock removal.

\section{Field Measurements}

At the beginning of each grazing season animals were weighed, stratified by initial weight, and within strata randomly assigned to pastures. Thereafter, weights were obtained at the start and then about every 30 days, and at the end of each annual trial. Initial weights of animals averaged $348 \mathrm{~kg}(\mathrm{SD}=29)$ in 1997,363 $\mathrm{kg}(\mathrm{SD}=20)$ in 1998 , and $363 \mathrm{~kg}(\mathrm{SD}=20)$ in 1999. Animals were treated with Ivermectin ${ }^{1}$ (Merck \& Co. Inc., Whitehouse Station, N.J.) before the study for parasite control and received an ear tag with fly repellent at the beginning of the grazing season. Trace mineralized salt was available at all times.

Standing crop was sampled during the weeks livestock were weighed by clipping forage to ground level in fifteen, $0.25 \mathrm{~m}^{2}$ quadrats in each 3-ha pasture. Forage samples were oven dried in a forced draft oven at $60^{\circ} \mathrm{C}$ and weighed. May 1997 and April 1998 and 1999 samples were separated into the following 4 portions: green tissue of seeded species, other grasses, and forbs and standing dead herbage. Samples collected during June 1997 and May and June 1998 and 1999, the middle and end of the grazing period, were separated by seeded species (live + dead or senesced tissue) and other species (live + dead or senesced tissue). Dead biomass simply reflects the combination of forage remaining after the grazing season plus that which was produced after cattle were removed. Relatively large amounts $\left(1,000 \mathrm{~kg} \mathrm{ha}^{-1}\right)$ of dead may remain standing over winter when snow cover is light. 
Diets were sampled monthly for each seeded grass during the week animals were weighed in 1998 and 1999. Six to 8 esophageally cannulated crossbred cows were used for diet sample collection. Diets were collected from 2 cows per pasture in 1998 and 3 cows per pasture in 1999 , but not all pastures were sampled with the same cows. Cows were penned at 1600 hours with water but no feed available. Collections were made the following morning beginning at 0700 hours. Collection periods lasted from 20 to 30 min. and were followed immediately by a collection in a second pasture. Esophageal masticate samples were thoroughly mixed by hand, and freeze dried for diet quality analyses. These cows were about 3 to 5 years old when sample collections began. Cows had been cannulated at 2 months of age and were experienced with the diet collection process. Between sampling periods, cows were kept in larger pastures with a variety of range sites but not the grass cultivars being assessed. However, cows had been previously exposed to all plant species present in the experimental pastures.

\section{Laboratory Analysis}

Two (1998) or 3 (1999) esophageal masticate samples per pasture and 3 standing crop samples of each vegetation component per pasture were ground to pass through a 1-mm screen in a Wiley mill ${ }^{1}$ (Arthur H. Thomas Co., Philadelphia, Penn.). Total nitrogen (N) (organic matter basis) was determined on a $\mathrm{C}-\mathrm{N}$ analyzer (Carlo-Erba ${ }^{1}$, C.E. Elantech, Inc., Lakewood, N.J.). Data are presented as CP standing crop $(\% \mathrm{~N} * 0.0625 * \mathrm{~kg}$ standing crop) and percentage CP in diets. In vitro digestible organic matter (IVDOM) was determined using a modified Tilley and Terry (1963) technique (White et al. 1981). Data are presented as digestible organic matter (OM) standing crop and percentage IVDOM in diets. Crude protein and IVDOM standing crop were summations of all live and dead vegetation components.

\section{Data Summarization and Analysis}

Analysis of variance was used to test effects of treatments (seeded species), dates, and interaction between them on standing crop, forage quality, diet quality, and livestock gains. Treatment effects were tested using variation among pastures within treatment as the error term. Effects of date and interaction of date with treatment were tested with residual variation after accounting for all other effects in
Table 1. Means for spring standing crops1 (significant seeded species by date interaction); standard errors equal $\pm \mathbf{8 2 . 1}$ for seeded species, $\pm \mathbf{3 5 . 8}$ for forbs, and $\pm \mathbf{1 1 0 . 6}$ for standing dead.

\begin{tabular}{lccc}
\hline \hline Groups/Years & Hycrest & Luna & Rosana \\
\hline Seeded species & $\cdots \ldots \ldots \ldots \ldots \ldots \ldots$ & $608^{\mathrm{Ba}}$ \\
1997-May & $912^{\mathrm{Ab} 2}$ & $448^{\mathrm{Bb}}$ & $750^{\mathrm{Ba}}$ \\
1998-April & $1,223^{\mathrm{Aa}}$ & $680^{\mathrm{Ba}}$ & $723^{\mathrm{Aa}}$ \\
1999-April & $617^{\mathrm{Ac}}$ & $594^{\mathrm{Aab}}$ & $183^{\mathrm{Aa}}$ \\
Forbs & $143^{\mathrm{Ab}}$ & $136^{\mathrm{Aa}}$ & $6^{\mathrm{Aa}}$ \\
1997-May & $17^{\mathrm{Ac}}$ & $82^{\mathrm{Aa}}$ & $96^{\mathrm{Ba}}$ \\
1998-April & $261^{\mathrm{Aa}}$ & $119^{\mathrm{Ba}}$ & $644^{\mathrm{Ab}}$ \\
1999-April & $666^{\mathrm{Ab}}$ & $530^{\mathrm{Ab}}$ & $1,548^{\mathrm{Aa}}$ \\
Standing dead & $1,039^{\mathrm{Ba}}$ & $886^{\mathrm{Ba}}$ & $428^{\mathrm{Bb}}$ \\
1997-May & $901^{\mathrm{Aab}}$ & $886^{\mathrm{Aa}}$ & \\
1998-April & 1999-April & &
\end{tabular}

${ }^{1}$ Samples collected in May 1997 and April 1998 and 1999, the beginning of the grazing period, were separated into the following 4 portions: green tissue of seeded species, other grasses, and forbs and standing dead.

${ }^{2}$ Within a plant group and date, species means with the same uppercase superscripts are not different $(\mathrm{P}<0.05)$. Within a plant group and species, means of dates with the same lowercase superscripts are not different $(\mathrm{P}<0.05)$. the model. The Least Significant Difference (LSD) method ( $\mathrm{P} \leq 0.05)$ protected by a prior F-test $(\mathrm{P} \leq 0.05)$ was used for comparing treatment means. All differences discussed are significant at the $\mathrm{P} \leq 0.05$ level unless otherwise noted.

\section{Results}

\section{Impact of Environment}

Productive stands were established for each species following the dormant seeding in late autumn 1994. The excellent establishment of seeded stands was partially facilitated by greater than or near average amounts of precipitation in March through July 1995 (Fig. 1). In contrast, precipitation was less than the long-term average in April through June and August through October 1996. This lack of precipitation resulted in a partial die off of Luna stands, particularly on elevated portions of the pastures. We planned to begin grazing pastures in April 1997, but less than average precipitation from February through June 1997 slowed plant growth on seeded pastures. Thus, the 1997 trial was limited to the period from 9 May to 12 June. Greater than average precipitation during March 1998 and April 1999 maintained good plant growth and allowed grazing from April to June during each of these years.

\section{Growth and Persistence of Grasses}

Persistence of seeded stands was partially evaluated by comparing the amount of green biomass of seeded species in the spring standing crop. Hycrest produced the largest standing crop in spring 1997 and 1998. However, by spring 1999 standing crops were similar among all 3 seeded grasses (Table 1). Forbs were most productive on the Hycrest pastures in 1999. This finding combined with the decrease
Table 2. Means for early spring and summer standing $\operatorname{crops}^{1}$ (significant seeded species by date interaction); standard errors equal $\mathbf{\pm 1 9 0 . 0}$ for seeded species and $\mathbf{\pm 6 6 . 5}$ for other species.

\begin{tabular}{|c|c|c|c|}
\hline Groups/Years & Hycrest & Luna & Rosana \\
\hline & $\ldots-\ldots$ & $\left(\mathrm{kg} \mathrm{ha}^{-1}\right)-$ & $-\ldots$ \\
\hline \multicolumn{4}{|l|}{ Seeded } \\
\hline June 1997 & $533^{\mathrm{Ad} 2}$ & $330^{\mathrm{Ac}}$ & $469^{\mathrm{Ad}}$ \\
\hline May 1998 & $2,543^{\mathrm{Aa}}$ & $2,367^{\mathrm{Aa}}$ & $1,800^{\mathrm{Ba}}$ \\
\hline June 1998 & $1,643^{\mathrm{Ab}}$ & $1,032^{\mathrm{Bb}}$ & $889^{\mathrm{Bcd}}$ \\
\hline May 1999 & $1,294^{\mathrm{ABbc}}$ & $890^{\mathrm{Bb}}$ & $1,470^{\mathrm{Aab}}$ \\
\hline June 1999 & $901^{\text {Acd }}$ & $701^{\mathrm{Abc}}$ & $1,015^{\mathrm{Abc}}$ \\
\hline \multicolumn{4}{|l|}{ Other species } \\
\hline June 1997 & $13^{\mathrm{Ab}}$ & $44^{\mathrm{Ac}}$ & $5^{\mathrm{Ab}}$ \\
\hline May 1998 & $27^{\mathrm{Ab}}$ & $153^{\mathrm{Abc}}$ & $29^{\mathrm{Ab}}$ \\
\hline June 1998 & $103^{\mathrm{ABb}}$ & $341^{\mathrm{Ab}}$ & $73^{\mathrm{Bab}}$ \\
\hline May 1999 & $398^{\mathrm{Ba}}$ & $1,055^{\mathrm{Aa}}$ & $298^{\mathrm{Ba}}$ \\
\hline June 1999 & $346^{\mathrm{Ba}}$ & $966^{\mathrm{Aa}}$ & $234^{\text {Bab }}$ \\
\hline
\end{tabular}

Samples collected during June 1997 and May and June 1998 and 1999, the middle and end of the grazing period, were separated by seeded species (live plus dead or senesced tissue) and other species (live plus dead or senesced tissue).

${ }^{2}$ Within a plant group and date, species means with the same uppercase superscripts are not different $(\mathrm{P}<0.05)$. Within a plant group and species, means of dates with the same lowercase superscripts are not different $(\mathrm{P}<0.05)$. 
Table 3. Means for IVDOM standing crops (date main effects); standard error equals $\pm \mathbf{7 5 . 5}$.

\begin{tabular}{|c|c|c|c|c|c|c|c|}
\hline \multicolumn{2}{|c|}{1997} & \multicolumn{3}{|c|}{1998} & \multicolumn{3}{|c|}{1999} \\
\hline May & June & April & May & June & April & May & June \\
\hline - - - - & d & - & $-\cdots$ & $-\cdots$ & $\cdots$ & $-\cdots$ & \\
\hline $889^{\text {bc1 }}$ & $309^{d}$ & $1,307^{\mathrm{a}}$ & $1,445^{\mathrm{a}}$ & $723^{c}$ & $968^{b}$ & $1,240^{\mathrm{a}}$ & $846^{\mathrm{bc}}$ \\
\hline
\end{tabular}

${ }^{1}$ Means of dates with same lowercase superscripts are not different $(\mathrm{P}<0.05)$.

in standing crop of Hycrest in 1999 suggested the Hycrest stand may have thinned. Standing crop of Luna and Rosana were almost similar among years. Dead biomass, which simply reflects the combination of forage remaining after the grazing season plus that which was produced after cattle were removed, averaged over $1,000 \mathrm{~kg} \mathrm{ha}^{-1}$ in 1998 in both the Hycrest and Rosana pastures. This large amount resulted from greater than average precipitation in July and October 1997 (Fig. 1). Neither species nor year significantly affected the amount of other grasses growing in each pasture $\left(\bar{x}=36 \mathrm{~kg} \mathrm{ha}^{-1} \mathrm{SD}\right.$ $=104)$.

Standing crops of all 3 seeded species had declined during the grazing period to near $500 \mathrm{~kg} \mathrm{ha}^{-1}$ in June 1997 and $872 \mathrm{~kg}$ $\mathrm{ha}^{-1}$ in June 1999, but standing crops were similar among species for these 2 periods (Table 2). In contrast, over $1,500 \mathrm{~kg} \mathrm{ha}^{-1}$ of Hycrest remained in June 1998, which was significantly greater than the $1,000 \mathrm{~kg}$ $\mathrm{ha}^{-1}$ remaining on Luna and $900 \mathrm{~kg} \mathrm{ha}^{-1}$ remaining on Rosana pastures. Standing crop of other plant species was less than $350 \mathrm{~kg} \mathrm{ha}^{-1}$ through June 1998 for all species. However, a trend of increasing amounts of other species began for all 3 treatment species, but especially for Luna pastures in June 1997, continued through 1998, and was significant in 1999.

\section{Forage Quality}

Digestible organic matter (OM) standing crop did not differ among seeded species (data not shown), but declined ( $\mathrm{P} \leq 0.05)$ during the grazing period from May to June each year (Table 3). The numerical increase in digestible OM standing crop from April to May was not significant in 1998 but was significant in 1999. In vitro digestible $O M$ concentration of green seeded grass herbage was $>80 \%$ in April while concentrations of green plus dead or senesced seeded grass herbage were $>60 \%$ in May and $>50 \%$ in June.

Crude protein (CP) standing crop varied among seeded species $(\mathrm{P} \leq 0.05)$ in April and May 1998 and May 1999 (Table 4). However, no clear trends were detected among seeded species. Crude protein standing crop consistently decreased from April-May to June. The only exception

The species by date interaction was also was the nonsignificant decline from May to June for Hycrest in 1999. Crude protein concentration of green seeded grass herbage was $>17 \%$ in April and May (1997) while concentrations of green plus dead or senesced seeded grass herbage were $>11 \%$ in May and $>9 \%$ in June. The species by date interaction was significant for CP of seeded grasses. Crude protein of seeded grasses differed on 4 out of 8 dates. No clear trends were detected among seeded species in April and May 1998. However, $\mathrm{CP}$ of green plus dead herbage for Luna $(13.4 \pm 0.01 \%)$ was greater than in Hycrest and Rosana $(\overline{\mathrm{x}}=9.8 \pm 0.01 \%)$ in June 1999 and Hycrest $(14.8 \pm 0.01 \%$ vs $11.6 \pm 0.01 \%$ ) in May 1999 . significant for CP of other grasses. A difference occurred among the seeded cultivars on 1 date, June 1999, when other grasses growing on Hycrest plots contained greater concentrations of CP (16.9 $\pm 0.01 \%$ ) than grasses growing on the Luna and Rosana pastures $(\bar{x}=10.5 \pm$ $0.01 \%)$. Crude protein of standing dead varied significantly only among dates and not among seeded species. Crude protein

Table 4. Means for CP standing crop (seeded species by date interaction); standard error equals \pm 27.1 .

\begin{tabular}{|c|c|c|c|}
\hline \multirow[b]{2}{*}{ Dates } & \multicolumn{3}{|c|}{ Seeded species } \\
\hline & Hycrest & Luna & Rosana \\
\hline & - & $\left(\mathrm{kg} \mathrm{ha}^{-1}\right.$ & \\
\hline 1997 May & $228^{\text {Acd } 1}$ & $157^{\mathrm{Ac}}$ & $190^{\text {Aab }}$ \\
\hline June & $82^{\mathrm{Ae}}$ & $62^{\mathrm{Ad}}$ & $71^{\mathrm{Ac}}$ \\
\hline 1998 April & $322^{\text {Aab }}$ & $243^{\text {Bab }}$ & $260^{\mathrm{ABa}}$ \\
\hline May & $359^{\mathrm{Aa}}$ & $316^{\text {Aab }}$ & $197^{\text {Bab }}$ \\
\hline June & $155^{\text {Ade }}$ & $139^{\mathrm{Ac}}$ & $113^{\mathrm{Ac}}$ \\
\hline 1999 April & $270^{\mathrm{Abc}}$ & $236^{\mathrm{Ab}}$ & $207^{\text {Aab }}$ \\
\hline May & $212^{\text {Bde }}$ & $304^{\mathrm{Aa}}$ & $234^{\mathrm{ABa}}$ \\
\hline June & $144^{\mathrm{Ae}}$ & $167^{A c}$ & $135^{\mathrm{Abc}}$ \\
\hline
\end{tabular}

${ }^{T}$ Within a date, species means with the same uppercase superscripts are not different $(\mathrm{P}<0.05)$. Within a species, means of dates with the same lowercase superscripts are not different $(\mathrm{P}<0.05)$.

Table 5. Means for IVDOM concentrations in diets collected on the experimental pastures in 1998 and 1999; standard error equals \pm 1.3 .

\begin{tabular}{|c|c|c|c|c|c|c|}
\hline \multirow[b]{2}{*}{ Species } & \multicolumn{3}{|c|}{1998} & \multicolumn{3}{|c|}{1999} \\
\hline & April & May & June & April & May & June \\
\hline Hycrest & $78^{\mathrm{ABb} 1}$ & $76^{\mathrm{Abc}}$ & $73^{\mathrm{Ac}}$ & $83^{\mathrm{Aa}}$ & $79^{\mathrm{Ab}}$ & $68^{\mathrm{Ad}}$ \\
\hline Luna & $80^{\mathrm{Aa}}$ & $71^{\mathrm{Bb}}$ & $72^{\mathrm{Ab}}$ & $81^{\mathrm{Aa}}$ & $78^{\mathrm{Aa}}$ & $67^{\mathrm{Ac}}$ \\
\hline Rosana & $76^{\mathrm{Bb}}$ & $66^{\mathrm{Cc}}$ & $67^{\mathrm{Bc}}$ & $83^{\mathrm{Aa}}$ & $78^{\mathrm{Ab}}$ & $69^{\mathrm{Ac}}$ \\
\hline
\end{tabular}

Within a date, species means with the same uppercase superscripts are not different $(\mathrm{P}<0.05)$. Within a species, means of dates with the same lowercase superscripts are not different $(\mathrm{P}<0.05)$. 
Table 6. Means for crude protein (CP) in diets collected on the experimental pastures in 1998 and 1999 ; standard error equals \pm 1.3 .

\begin{tabular}{|c|c|c|c|c|c|c|}
\hline \multirow[b]{2}{*}{ Species } & \multicolumn{3}{|c|}{1998} & \multicolumn{3}{|c|}{1999} \\
\hline & April & May & June & April & May & June \\
\hline $\begin{array}{l}\text { Hycrest } \\
\text { Luna } \\
\text { Rosana }\end{array}$ & $\begin{array}{l}22^{\mathrm{ABa} 1} \\
25^{\mathrm{Aa}} \\
19^{\mathrm{Ba}}\end{array}$ & $\begin{array}{l}19^{\mathrm{Aab}} \\
16^{\mathrm{Bc}} \\
11^{\mathrm{Bb}}\end{array}$ & $\begin{array}{l}22^{\mathrm{Aa}} \\
22^{\mathrm{Aab}} \\
14^{\mathrm{Bb}}\end{array}$ & $\begin{array}{l}\% 1^{\mathrm{Aa}} \\
23^{\mathrm{Aa}} \\
20^{\mathrm{Aa}}\end{array}$ & $\begin{array}{l}17^{\mathrm{ABbc}} \\
19^{\mathrm{Abc}} \\
15^{\mathrm{Bb}}\end{array}$ & $\begin{array}{l}14^{\mathrm{Ac}} \\
12^{\mathrm{Ad}} \\
14^{\mathrm{Ab}}\end{array}$ \\
\hline
\end{tabular}

${ }^{\mathrm{T}}$ Within a date, species means with the same uppercase superscripts are not different $(\mathrm{P}<0.05)$. Within a species, means of dates with the same lowercase superscripts are not different $(P<0.05)$.

1998. Gains per hectare were greater for Hycrest $\left.178 \pm 7.2 \mathrm{~kg} \mathrm{ha}^{-1}\right)$ than for both Luna and Rosana $\left(\overline{\mathrm{x}}=148 \pm 7.2 \mathrm{~kg} \mathrm{ha}^{-1}\right)$. This may reflect the lowered IVDOM observed for Rosana compared to Hycrest in 1998. Daily gains per head (Table 7) and gains per hectare on Hycrest and Rosana $\left(\overline{\mathrm{x}}=104 \pm 7.2 \mathrm{~kg}^{-1}\right)$ were greater than on Luna $\left(72 \pm 7.2 \mathrm{~kg} \mathrm{ha}^{-1}\right)$ in 1999.

The lack of sensitivity of weight gains to nutritional quality may partially be a reflection of the technique used to measure IVDOM. Addition of $\mathrm{N}$ to IVDOM media, as in these analyses, has been shown to mask differences in response to Northern Great Plains forages such that weight gains of steers grazing native rangeland were better predicted by IVDOM media without supplemental $\mathrm{N}$ compared to that with $\mathrm{N}$ (Blummel et al. 2001).

Steer gains in 1997 and 1998 were 40\% greater than heifer gains in 1999 (Table 7). Gains per hectare for Hycrest and Rosana were greatest in 1998, intermediate in 1999, and least in 1997. In contrast, gains per hectare on Luna were greatest in 1998 $\left(152 \pm 7.2 \mathrm{~kg} \mathrm{ha}^{-1}\right)$, but gains in $1999(72 \pm$ $7.2 \mathrm{~kg} \mathrm{ha}^{-1}$ ) were similar to those during the shortened grazing period in $1997(\overline{\mathrm{x}}=$ $68 \pm 7.2 \mathrm{~kg} \mathrm{ha}^{-1}$ ).

\section{Discussion}

Seedings of new cultivars are used to increase available forage and to extend the period of high quality forage for grazing livestock (Wasser 1982, Holzworth et al. 2000, Vallentine 1980). Crested wheatgrass has traditionally been used for spring grazing and in some instances autumn grazing (Vallentine 1980). Pubescent wheatgrass is used during the spring and summer (Holzworth et al. 2000). Western wheatgrass, a native to Northern Great Plains rangelands, provides valuable forage during the spring, summer, and autumn (Wasser 1982).

Data from this study and others clearly show that in some years, crested wheat- grass provides more forage than selected cultivars of native species e.g., western wheatgrass and native range (Smoliak 1968, Hart et al. 1983, Adams et al. 1989) and will allow an increase in livestock numbers. However, this does not occur every year in every region. This occurred in 1 out of 3 years when Hycrest was compared to Rosana, a selected cultivar of western wheatgrass in our study. Willms and Jefferson (1993) reported relative above-ground production of native mixed prairie vs seeded monocultures is not consistent among production years or studies. Others are also concerned about the negative effect introduced plant species, e.g., crested wheatgrass, can have on native species, biodiversity, and soils (Dormaar et al. 1995, Lesica and DeLuca 1996, Christian and Wilson 1999, Krzic et al. 2000). Some results suggest seedings of crested wheatgrass in the Northern Great Plains may reduce biodiversity and alter pools and flows of energy and nutrients in the seeded areas within the prairie ecosystem. Based on these findings, Lesica and DeLuca (1996) cautioned that the continued conversion of native prairie by plowing and planting crested wheatgrass or other exotic species seemed ill advised.

Concerns about the persistence of pubescent wheatgrass in the $335 \mathrm{~mm}$ precipitation zone were first raised by Currie and White (1982). During a prolonged drought, they found cultivars of the intermediate-pubescent wheatgrass complex to be killed or to be the most severely damaged of a number of grass species frequently seeded in the Northern Great Plains.

Livestock performance varies among

Table 7. Means for average daily gain of yearling cattle; standard errors equal \pm 0.03 for species, \pm 0.08 for year, and \pm 0.04 for species by year interaction.

\begin{tabular}{llccc}
\hline \hline Year & Hycrest & Luna & Rosana & Mean \\
\hline & $1.13^{\mathrm{Aal}}$ & $1.05^{\mathrm{Aa}}$ & $1.26^{\mathrm{Aa}}$ & $1.15^{\mathrm{a}}$ \\
1997 & $1.28^{\mathrm{Aa}}$ & $1.09^{\mathrm{ABa}}$ & $1.03^{\mathrm{Bb}}$ & $1.14^{\mathrm{a}}$ \\
1998 & $0.74^{\mathrm{Ab}}$ & $0.52^{\mathrm{Bb}}$ & $0.78^{\mathrm{Ac}}$ & $0.68^{\mathrm{b}}$ \\
1999 & $1.05^{\mathrm{A}}$ & $0.89^{\mathrm{B}}$ & $1.03^{\mathrm{A}}$ & \\
Mean & & $\left.\mathrm{day}^{-1}\right)$ & \\
\hline
\end{tabular}

${ }^{\mathrm{W}}$ Within a date, species means with the same uppercase superscripts are not different $(\mathrm{P}<0.05)$. Within a species, means of dates with the same lowercase superscripts are not different $(\mathrm{P}<0.05)$. variety becomes more challenging as new seeded pastures and native range (Houston and Urick 1972, Hart et al. 1983, Adams et al. 1989, Hofmann et al. 1993). While some report increases in individual animal performance from grazing seeded ranges (Houston and Urick 1972) others report the main advantage of seeded ranges appears to be increased seasonal carrying capacity (Hart et al. 1983, Adams et al. 1989, Hofmann et al. 1993). Adams et al. (1989) imply that animal performance will not differ greatly among seeded pastures and native range in good-to-excellent condition that contains a high component of cool-season perennial grasses. Greater differences may occur when native range contains a higher proportion of warm-season perennial grasses.

\section{Management Implications}

Willms and Jefferson (1993) suggested a crucial question is not which species to seed but whether seeding should be done at all on many sites. However, seeding cool-season monocultures on western rangelands provides livestock managers with another tool to increase available forage and provide quality forage for grazing livestock. Choosing the best forage for the intended use is critical. Choosing the best varieties are released from both the public and private sectors. Seeding is not a panacea, but many livestock operations can benefit from the use of an integrated management strategy using both rangelands and seeded cool-season monocultures. Learning more about the growth and quality characteristics of new forages is a key first step in developing a successful management strategy which includes seeded forages.

Careful assessment of both the suitability of a planted species for the intended use and the hazard of undesired consequences, e.g., negative impacts on soil and indigenous vegetation, should precede any pasture or rangeland planting. The levels of productivity and persistence of Rosana make this selected native cultivar of west- 
ern wheatgrass a viable option when managers prefer using natives. However, the potential for greater animal gain in some environmental conditions (1998) confirms that Hycrest crested wheatgrass can be a useful forage plant for livestock production in the region. Based on the encroachment of invading species, persistence of Luna is marginal in the $335-\mathrm{mm}$ precipitation zone in the Northern Great Plains.

\section{Literature Cited}

Adams, D.C., R.B. Staigmiller, and B.W. Knapp. 1989. Beef production from native and seeded Northern Great Plains ranges. J. Range Manage. 42:243-247.

Blummel, M., E.E. Grings, and M.R. Haferkamp. 2001. Predicting weight gain of grazing steers by the kinetics of in vitro gas production of extrusa samples fermented in nitrogen supplemented and unsupplemented incubation medium. European Assoc. Anim. Prod. Symp. p.19-20.

Borman, M.M., D.C. Adams, B.W. Knapp, and M.R. Haferkamp. 1991. Evaluation of dietary preference with a multiple latin square design. J. Range Manage. 44:295-296.

Christian, J.M. and S.D. Wilson. 1999. Longterm ecosystem impacts of an introduced grass in the Northern Great Plains. Ecol. 80:2397-2407.

Currie, P.O. and R.S. White. 1982. Drought survival of selected forage grasses commonly seeded in the Northern Great Plains. Can. J. Plant Sci. 62:949-955.

Currie, P.O., L.R. Erickson, and R.S. White. 1986a. Productivity changes from multiple renovation practices on Northern Great Plains rangelands, p. 306-307. In: P.J. Joss, P.W. Lynch, and O.B. Williams (eds.) Rangelands: A resource under siege. Proc 2nd Intl. Rangel. Cong. Australia Acad. of Sci., Canberra.

Currie, P.O., T.O. Hilken, and R.S. White. 1986b. Field evaluation of five grasses grown on a saline soil. J. Range Manage. $39: 386-388$
Dormaar, J.F., A. Naeth, W.D. Willms, and D.S. Chanasyk. 1995. Effect of native prairie, crested wheatgrass (Agropyron cristatum (L.) Gaertn.) and Russian wildrye (Elymus junceus Fisch.) on soil chemical properties. J. Range Manage. 48:258-263.

Hart, R.H., J.W. Waggoner, D.H. Clark, C.C. Kaltenbach, J.A. Hager, and M.B. Marshall. 1983. Beef cattle performance on crested wheatgrass plus native range vs. native range alone. J. Range Manage. 36:38-40.

Hofmann, L., R.E. Ries, J.F. Karn, and A.B. Frank. 1993. Comparison of seeded and native pastures grazed from mid-May through September. J. Range Manage. 46:251-254.

Holzworth, L., J. Mosley, D. Cash, D. Koch, and K. Crane. 2000. Dryland pastures in Montana and Wyoming. Montana State Univ. Extension Serv. EB 19. Revised Sept. 2000. Bozeman, Mont.

Houston, W.R. and J.J. Urick. 1972. Improved spring pastures, cow-calf production, and stocking rate carryover in the Northern Great Plains. USDA-ARS Tech. Bull. No. 1451. Washington, D.C.

Kilcher, M.R. and T. Lawrence. 1979. Spring and summer pastures for southwestern Saskatchewan. Can. J. Plant Sci. 59:339-342.

Krzic, M., K. Broersma, D.J. Thompson, and A.A. Bomke. 2000. Soil properties and species diversity of grazed crested wheatgrass and native rangelands. J. Range Manage. 53:353-358

Küchler, A.W. 1964. Potential natural vegetation of the conterminous United States. Amer. Geog. Soc. Spec. Pub. 36. Amer. Geog. Soc. New York, N.Y.

Lesica, P. and T.H. DeLuca. 1996. Long-term harmful effects of crested wheatgrass on Great Plains grassland ecosystems. J. Soil Water Conserv. 51:408-409.

Moore, K.J., K.P. Vogel, T.J. Klopfenstein R.A. Masters, and B.E. Anderson. 1995. Evaluation of four intermediate wheatgrass populations under grazing. Agron. J. 87:744-747.

National Oceanic and Atmospheric Administration. 1994-1999. Climatological data annual summary, Montana. 94-99:13. Nat. Climatol. Data Center, Asheville, N.C.
Papadopoulos, Y.A., M.A. Price, G.M. Hunter, K.B. McRae, L.F. Laflamme, C.D. Caldwell, and N.R. Fulton. 1995. Differences among orchardgrass cultivars in response to hay and rotational grazing management. Can. J. Plant Sci. 75:147-157.

Smoliak, S. 1968. Grazing studies on native range, crested wheatgrass, and Russian wildrye pastures. J. Range Manage. 21:47-50.

Smoliak, S. and S.B. Slen. 1974. Beef production on native range, crested wheatgrass, and Russian wildrye pastures. J. Range Manage. 27:433-436.

Tilley, J.M.A. and R.A. Terry. 1963. A twostage technique for the in vitro digestion of forage crops. J. Brit. Grassl. Soc. 18:104-111.

Truscott, D.R. and P.O. Currie. 1989. Cattle preference for a hybrid grass: chemical and morphological relationships. J. Range Manage. 42:22-27.

Vallentine, J.F. 1980. Range development and improvements. Second edition. Brigham Young University Press. Provo, Utah.

Vogel, K.P., B.C. Grabrielsen, J.K. Ward, B.E. Anderson, H.F. Mayland, and R.A. Masters. 1993. Forage quality, mineral constituents, and performance of beef yearlings grazing two crested wheatgrasses. Agron. J. 85:584-590.

Wasser, C.H. 1982. Ecology and culture of selected species useful in revegetating disturbed land in the west. Biological Services Program, Fish and Wildlife Serv., U.S. Dept. of Interior. NTIS, U.S. Dept. of Commerce, Springfield, Virg.

White, L.M., G.P. Hartman, and J.W. Bergman. 1981. In vitro digestibility, crude protein, and phosphorus content of straw of winter wheat, spring wheat, barley, and oat cultivars in eastern Montana. Agron. J. 73:117-121.

Wight, J.R., C.K. Gee, and R.J. Kartchner. 1983. Integrated rangeland and cropland management, p. 435-460. Dryland agriculture. Agronomy Monograph No. 23. ASACSA-SSSA, Madison, Wis.

Willms, W.D. and P.G. Jefferson. 1993. Production characteristics of the mixed prairie: constraints and potential. Can. J. Anim. Sci. 73:765-778. 